

PNL-SA-24672

\title{
VITRIFICATION OF HIGH SULFATE WASTES
}

\author{
R. A. Merrill \\ K. F. Whittington \\ R. D. Peters
}

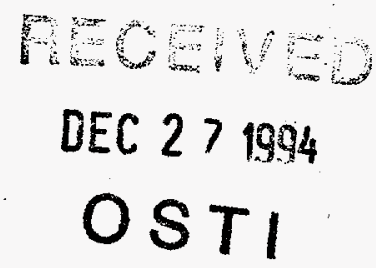

September 1994

Presented at the

I \& EC Special Symposium

September 19-21, 1994

Atlanta, Georgia

Prepared for

the U.S. Department of Energy

under Contract DE-AC06-76RLO 1830

Pacific Northwest Laboratory

Richland, Washington 99352

\section{DISCLAIMER}

This report was prepared as an account of work sponsored by an agency of the United States Government. Neither the United States Government nor any agency thereof, nor any of their employees, makes any warranty, express or implied, or assumes any legal liability or responsibility for the accuracy, completeness, or usefulness of any information, apparatus, product, or process disclosed, or represents that its use would not infringe privately owned rights. Reference herein to any specific commercial product, process, or service by trade name, trademark, manufacturer, or otherwise does not necessarily constitute or imply its endorsement, recommendation, or favoring by the United States Government or any agency thereof. The views and opinions of authors expressed herein do not necessarily state or reflect those of the United States Government or any agency thereof. 


\section{DISCLAIMER}

Portions of this document may be illegible in electronic image products. Images are produced from the best available original document. 


\author{
PREPRINT EXTENDED ABSTRACT \\ Presented at the I\&EC Special Symposium \\ American Chemical Society \\ Atlanta, GA, September 19-21, 1994 \\ VITRIFICATION OF HIGH SULFATE WASTES \\ R.A.Merrill, K.F. Whittington, R.D. Peters \\ Pacific Northwest Laboratory* , Richland, WA 99352
}

\title{
Introduction
}

The U.S. Department of Energy (DOE) through the Mixed Waste Integrated Program (MWIP) is investigating the application of vitrification technology to mixed wastes within the DOE system. This work involves identifying waste streams, laboratory testing to identify glass formulations and characterize the vitrified product, and demonstration testing with the actual waste in a pilot-scale system. Part of this program is investigating process limits for various waste components, specifically those components that typically create problems for the application of vitrification, such as sulfate, chloride, and phosphate. This work describes results from vitrification testing for a high-sulfate waste, the 183-H Solar Evaporation Basin waste at Hanford.

The 183-H Solar Evaporation Basin waste actually consists of approximately 5,000 tons of several different waste streams. The major waste streams identified in the closure plan are sludge, crystalline material, and solidified liquid (1). Adsorbent material (diatomaceous earth) also comprises a significant fraction of the waste since it was added to drums along with the sludge and crystalline material. The composition of a composite of the different waste streams was calculated based on the relative amounts of material in the different waste fractions, and a surrogate material was made to simulate this combination of the actual waste materials. Table 1 presents the composition of the surrogate material used in these tests.

The waste is predominantly sodium nitrate and sulfate, along with significant amounts of copper, zirconium, and calcium (from the grout used to solidify the liquid). The high nitrate in the waste does not pose a processing problem for vitrification because the nitrates are readily decomposed at temperatures below the melting temperatures of glass. Sulfate, however, is more thermally stable, and when present in silicate glasses in amounts greater than about $1 \mathrm{wt} \%$, can combine with alkali in the glass to form a molten salt phase on the surface of the melt. Decomposition of the alkali sulfates normally occurs only at relatively high temperatures (greater than $1300^{\circ} \mathrm{C}$ ). The two-phase condition resulting from sulfate in the waste is undesirable due to effects on the processing of the glass and the final waste form. Water-soluble sulfates are not suitable as a waste form; some elements and radionuciides may concentrate in this watersoluble phase. A conductive layer may short the electrodes, and the accumulation of molten salt may fill much of the melter unless removed. Efforts in this work focused on formulating glasses so that the sulfate is decomposed and driven off from the melt as gaseous oxides.

Results

Melts were generally carried out by mixing the surrogate material and desired additives and holding the mixture in a furnace at the desired temperature for at least an hour. The melts were then typically removed from the furnace and poured. The viscosity was estimated by visual observation during pouring. The resulting glass was leach tested by either the Toxicity Characteristic Leaching Procedure (TCLP) or a modification of the TCLP using deionized (DI) water as the leachant. Results were compared to reference glasses leached by the same methods to obtain a preliminary assessment of durability.

A number of melts were performed in the silicate glass system at temperatures of $1150^{\circ} \mathrm{C}$ to $1350^{\circ} \mathrm{C}$. In melts with glass formers alone as additives, separation of a molten salt layer (primarily sodium sulfate) was observed as expected due to the high sulfate content of the waste. Attempts were made to reduce the sulfate with additives such as carbon in order to drive off the sulfate from the melt as a gaseous oxide; however, this led to reduction of metals in the melt (primarily copper) and the formation of a copper

\footnotetext{
* Operated for the U.S. Department of Energy by Battelle Memorial Institute under Contract DE-ACO6-76RLO 1830.
} 
sulfide button on the bottom of the melt. In many instances, both the sulfate and a reduced phase were present in the same crucible. Melts of the same simulant composition, but without sulfate included, resulted in homogeneous, deep blue glasses, indicating that good glasses could be formed if the sulfate were somehow removed. The work confirmed the difficulties resulting from vitrification of sulfatecontaining wastes in a silicate glass system and did not show much promise unless the sulfate were first removed from the waste by some other process.

Phosphate glasses were next investigated as a means of dealing with high sulfate wastes. Sulfur can replace the oxygen in phosphate glasses more readily than in silicate systems (2), and there are reports in the literature of phosphate glasses containing sulfate in amounts up to $7 \mathrm{wt} \%(3,4)$. Therefore, a number of melts were carried out in the temperature range of $1000^{\circ} \mathrm{C}$ to $1200^{\circ} \mathrm{C}$ with phosphate glasses similar in composition to those reported to retain sulfate. Inductively coupled plasma spectroscopy (ICP) analysis of numerous melts found up to $1.5 \mathrm{wt} \% \mathrm{SO}_{3}$ in the vitrified product, not nearly as high as reported by others. Nevertheless, separation of a molten salt phase was not observed in any of these melts, even with a large excess of sulfate in the initial batch (up to $17 \mathrm{wt} \%$ ). It was apparent that the sulfate was being decomposed and driven off from the phosphate melt. This phenomenon was noted in early work with high-level waste vitrification (5). Decomposition of the sulfate by the phosphate glass formulation avoids the processing difficulties previously mentioned and potentially allows vitrification of high sulfate wastes. Further work examining the phosphate glasses that were developed is described below.

Table 2 reports the analyzed composition and other data pertaining to two glass formulations developed for the $183-\mathrm{H}$ wastes. The waste loading of the composite $183-\mathrm{H}$ waste in these melts is about $38 \%$ on a dry oxide basis (g waste oxide/g glass). SPP22 has a processing temperature of about $1050^{\circ} \mathrm{C}$, while SPP23 was melted at $1150^{\circ} \mathrm{C}$. Both form homogenous, dark blue-green glasses. The melts were spiked with $5000 \mathrm{ppm}$ of lead to better evaluate the ability of the glass to retain heavy metals, both during melting and leaching. It is evident that minimal volatilization occurred from analysis of the product glass. It is also evident from the analyses that most of the sulfate is evolved from these melts.

The glasses were tested for chemical durability by the TCLP and a similar test using DI water as the leachant. Three samples of each glass were leached by the TCLP, and one sample of each was tested by the DI Leach Procedure. Samples of the glasses that had been held at $850^{\circ} \mathrm{C}$ for 24 hours were also tested. Table 3 summarizes the results of these tests. The durability of these glasses is comparable to or better than reference high-level waste glasses. Additionally, devitrification of the samples does not appear to have a significant effect on the leachability of the melts.

Phosphate glasses are noted for their high corrosivity; therefore, the effect of the selected glass formulations on materials commonly found in melters that will be in contact with the molten glass was examined. Samples of Inconel 690 (Huntington Alloys, Inc.), Monofrax-E (Carborundum), and molybdenum were placed in crucibles and molten glass poured on the samples. The crucibles were held in a furnace at $1100^{\circ} \mathrm{C}$ for 24 hours. After 24 hours, the contents were poured out and examined. Table 4 presents a summary of the observations from these tests. Minimal corrosion of the molybdenum was observed in both glasses, while the Inconel was severely corroded by SPP23, but only minimally corroded by SPP 22.

A melt of the SPP23 composition was spiked with a SO 3 content ranging from 2 wt $\%$ to 17 wt\% in the batch. The analyzed sulfate content of the melted glasses ranged from about 1 wt $\%$ to 1.5 wt\% with no trace of a separate sulfate phase. The results of ICP analysis showed that only sulfate was significantly lost from the glass, indicating that the sulfate decomposed to gaseous oxides rather than volatilized as a salt. Although the sulfate is not retained in these melts, decomposition of the sulfate results in an effective separation within the melter, thereby avoiding problems with the formation of a secondary molten salt phase. Many other issues remain to be considered such as the volatility of other elements and nuclides in a continuous melter and the means of dealing with the sulfate after it is evolved from the melt. Nevertheless, these results show that high sulfate waste streams may be processable in a continuous melter.

\section{Conclusions}

A low melting phosphate glass formulation has been developed for a waste stream high in sodium and sulfate. At melt temperanures in the range of $1000^{\circ} \mathrm{C}$ to $1200^{\circ} \mathrm{C}$, sulfate in the waste is decomposed to gaseous oxides and driven off during melting, while the remainder of the oxides stay in the melt. Decomposition of the sulfates eliminates the processing problems typically encountered in vitrification of 
sulfate-containing wastes, resulting in separation of the sulfate from the remainder of the waste and allowing the sulfate to be collected in the off-gas system and treated as a secondary waste stream. Both the vitreous product and intentionally devitrified samples are durable when compared to reference glasses by TCLP and DI water leach tests. Simple, short tests to evaluate the compatibility of the glasses with potential melter materials found minimal corrosion with most materials.

Results from these tests demonstrate the potential for vitrification of high sulfate wastes using phosphate glasses. These results also demonstrate that consideration of glass systems beyond the soft-borosilicate glasses prevalent for high-level waste may allow much wider process limits for the variety of low-level and mixed waste streams throughout the DOE system.

\section{References}

1. U.S. Department of Energy, "183-H Solar Evaporation Basin Closure/Post-Closure Plan." DOE/RL 88-04 Rev. 2, April, 1990.

2. Volf, M. B. Chemical Approach to Glass. Elsevier Science Publishing Company, Inc., New York, New York, 1984.

3. Stefanovskii, S.V. and F.A. Lifanov. "Glasses for Immobilization of Sulfate-Containing Radioactive Wastes." Radiokhimiya, 31:6, pp. 129-134, November-December, 1989.

4. Ivanov, I.A., et al. "Diffusion of Sodium Cations and Water Resistance of Glasses for Immobilizing Medium-Level Wastes." Radiokhimiya, 33:5, pp. 122-127, September-October, 1991.

5. Moore, J.D. "Waste Solidification Engineering Prototypes, Design Verification Testing of Spray Solidification Equipment." BNWL-1117, Pacific Northwest Laboratory, Richland, Washington, July, 1969.

This work is funded by the Office of Technology Development, within the Department of Energy's Office of Environmental Management, under the Mixed Waste Integrated Program.

Table 1. Composition of the 183-H Waste Simulant (Dry Wt\% Basis)

\begin{tabular}{|c|c|}
\hline Component & $\mathrm{Wt} \%$ \\
\hline $\mathrm{Ag}_{2} \mathrm{O}$ & 0.03 \\
\hline $\mathrm{Al}_{2} \mathrm{O}_{3}$ & 1.73 \\
\hline $\mathrm{BaO}$ & 0.01 \\
\hline $\mathrm{CaO}$ & 12.04 \\
\hline $\mathrm{Ce}_{2} \mathrm{O}_{3}$ & 0.32 \\
\hline $\mathrm{Cr}_{2} \mathrm{O}_{3}$ & 0.15 \\
\hline $\mathrm{CuO}$ & 10.37 \\
\hline $\mathrm{Fe}_{2} \mathrm{O}_{3}$ & 0.93 \\
\hline $\mathrm{K}_{2} \mathrm{O}$ & 0.10 \\
\hline $\mathrm{MnO}$ & 0.98 \\
\hline $\mathrm{N}_{2} \mathrm{O}_{5}$ & 14.79 \\
\hline $\mathrm{Na}_{2} \mathrm{O}$ & 33.00 \\
\hline $\mathrm{NaF}$ & 5.69 \\
\hline $\mathrm{PbO}$ & 0.01 \\
\hline $\mathrm{SiO}_{2}$ & 7.63 \\
\hline $\mathrm{SO}_{3}$ & 6.78 \\
\hline $\mathrm{ZnO}$ & 0.07 \\
\hline $\mathrm{ZrO}_{2}$ & 5.37 \\
\hline Total & 100.00 \\
\hline
\end{tabular}


Table 2. Composition of 183-H Phosphate Glasses Based on ICP Analysis

\begin{tabular}{|l|r|r|}
\hline & \multicolumn{2}{|c|}{ Normalized Wt\% Oxide } \\
\cline { 2 - 3 } Oxide & SPP22 Pb & \multicolumn{1}{|c|}{ SPP23 Pb } \\
\hline $\mathrm{Ag}_{2} \mathrm{O}$ & 0.02 & 0.01 \\
$\mathrm{Al}_{2} \mathrm{O}_{3}$ & 18.39 & 21.08 \\
$\mathrm{~B}_{2} \mathrm{O}_{3}$ & 4.49 & \\
$\mathrm{BaO}_{\mathrm{CaO}}$ & 0.01 & 0.01 \\
$\mathrm{CeO}_{2}$ & 5.25 & 5.61 \\
$\mathrm{Cr}_{2} \mathrm{O}_{3}$ & 0.21 & 0.20 \\
$\mathrm{CuO}$ & 0.04 & 0.07 \\
$\mathrm{Fe}_{2} \mathrm{O}_{3}$ & 4.17 & 4.33 \\
$\mathrm{~K}_{2} \mathrm{O}$ & 0.51 & 0.52 \\
$\mathrm{MnO}^{\mathrm{N} O}$ & 0.94 & 0.78 \\
$\mathrm{Na}_{2} \mathrm{O}$ & 0.43 & 0.45 \\
$\mathrm{P}_{2} \mathrm{O}_{5}$ & 21.17 & 17.36 \\
$\mathrm{PbO}$ & 35.55 & 42.34 \\
$\mathrm{SO}_{3}$ & 0.67 & 0.53 \\
$\mathrm{SiO}_{2}$ & 1.62 & \\
$\mathrm{TiO}_{2}$ & 3.79 & 4.32 \\
$\mathrm{ZrO}_{2}$ & 0.02 & 0.03 \\
\hline \hline $\mathrm{TOtal}$ & 2.73 & 2.35 \\
\hline
\end{tabular}

Table 3. Comparison of Devirtified Glasses to Quenched Glasses

\begin{tabular}{|l|c|c|c|c|}
\hline & $\begin{array}{c}\text { Quenched } \\
\text { Glass - } \\
\text { DI H2O } \\
\left(\mathrm{g}_{2} \mathrm{O} \mathrm{m}^{2}\right)\end{array}$ & $\begin{array}{c}\text { Quenched } \\
\text { Glass - TCLP } \\
\left(\mathrm{g} / \mathrm{m}^{2}\right)\end{array}$ & $\begin{array}{c}\text { Devirrified } \\
\text { Samples - DI } \\
\mathrm{H}_{2} \mathrm{O} \\
\left(\mathrm{g} / \mathrm{m}^{2}\right)\end{array}$ & $\begin{array}{c}\text { Devitrified } \\
\text { Samples - } \\
\text { TCLP } \\
\left(\mathrm{g} / \mathrm{m}^{2}\right)\end{array}$ \\
\hline SPP22-Pb & 0.18 & 0.19 & 0.19 & 0.24 \\
SPP23-Pb & 0.17 & 0.14 & 0.16 & 0.21 \\
ARM-1 & 0.18 & 0.16 & - & - \\
DWPF-EA & 0.32 & 5.40 & - & - \\
\hline
\end{tabular}

Table 4. Melter Material Test Observations

\begin{tabular}{|l|l|l|l|}
\hline Glass & \multicolumn{1}{|c|}{ Inconel 690} & \multicolumn{1}{c|}{ Monofrax-E } & \multicolumn{1}{c|}{ Molybdenum } \\
\hline SPP-22 & $\begin{array}{l}\text { The sample is intact } \\
\text { with a little pitting } \\
\text { visible on the surface of } \\
\text { the glass. A layer of } \\
\mathrm{C}_{2} \mathrm{O}_{3} \text { formed at the } \\
\text { interface of the glass and } \\
\text { Inconel. }\end{array}$ & $\begin{array}{l}\text { The e-block was not } \\
\text { corroded by the glass. } \\
\text { Glass filled the pores of } \\
\text { the e-block }\end{array}$ & $\begin{array}{l}\text { The molybdenum } \\
\text { showed very little } \\
\text { corrosion. A reddish } \\
\text { layer was visible on the } \\
\text { outside of the moly. }\end{array}$ \\
\hline SPP-23 & $\begin{array}{l}\text { The Inconel sample } \\
\text { reacted with the glass } \\
\text { and was severely eroded. }\end{array}$ & $\begin{array}{l}\text { The e-block was not } \\
\text { corroded by the glass. } \\
\text { Glass filled the pores of } \\
\text { the e-block. }\end{array}$ & $\begin{array}{l}\text { The molybdenum } \\
\text { showed very little } \\
\text { corrosion. A reddish } \\
\text { layer was visible on the } \\
\text { outside of the moly. }\end{array}$ \\
\hline
\end{tabular}

* The layer was submitted for XRD analysis. The layer was composed of 1 ) $\mathrm{Cr}_{2} \mathrm{O}_{3}$ Conc. $=75$ wt\% (approx.); 2) Inconeltype structure present. Conc. $=10 \mathrm{wt} \%$ (approx.); 3) Cristobalite, $\mathrm{SiO}_{2}$ Conc. = $10 \mathrm{wt} \%$ (approx.); and 4) UNIDENTIFIED phase(s) $=5$ wt\% (approx.). 